Article

\title{
The Identification of Values in Business Models of Tourism Enterprises in the Context of the Phenomenon of Overtourism
}

\author{
Zygmunt Kruczek ${ }^{1, *(\mathbb{D})}$ and Adam R. Szromek ${ }^{2}$ (D) \\ 1 Department of Tourism Geography and Ecology, University School of Physical Education, \\ Al. Jana Pawła II 78, 31-571 Kraków, Poland \\ 2 Department of Organization and Management, Institute of Economy and Informatics, \\ Silesian University of Technology, Akademicka 2A, 44-100 Gliwice, Poland; innowator@o2.pl \\ * Correspondence: zygmunt.kruczek@awf.krakow.pl; Tel.: +48-602-758-513
}

Received: 8 February 2020; Accepted: 14 February 2020; Published: 15 February 2020

\begin{abstract}
This article presents considerations on business models, overtourism, and sustainable development on an example of the most important Polish tourist destination, which is Krakow. The purpose of the article is to identify the values generated and captured by tourist enterprises in the context of the occurrence of a specific level of overtourism. The authors have attempted to identify the values of sustainable tourism declared by entrepreneurs, referring to the companies providing services as well as tourists and the local community. The research, conducted on a sample of 518 respondents including 371 residents and 147 entrepreneurs, not only allowed us to determine the attitudes of Krakow inhabitants toward the phenomenon of overtourism related to the Doxey model of irritation, but also to assess the impact of having/using a business model based on the acceptance of principles in sustainable tourism development. A comparison of the results obtained between enterprises declaring having and not having a business model indicates a great similarity in terms of declared value propositions.
\end{abstract}

Keywords: sustainability; overtourism; business model; Doxey model; Krakow

\section{Introduction}

The negative impact of tourist activities in the area of tourist destinations is one of the key problems of modern tourism. Balancing the expectations of tourists and residents not only becomes the task of local authorities in a tourist destination, but also that of the entrepreneurs conducting these activities. The literature proves that the enterprise's use of a tool in the form of a business model streamlines and organizes their operations. It allows, among others, for mistakes to be avoided in the form of the omission of actions necessary to achieve market success. In recent years, care for the natural environment and the local culture of inhabitants has become one of these tasks. However, these elements are rarely included in the business models of modern enterprises.

The purpose of the article is to identify the values generated and captured by tourist enterprises in the context of the occurrence of a specific level of overtourism on the example of the historic city of Krakow. The paper is based on research conducted in 2019 among the inhabitants and tourism entrepreneurs of this tourist city. Although Krakow, as the most recognizable tourist destination in Poland and Central Europe, shows signs of an excessive concentration of visitors, the level of tourist traffic load here is rather moderate, excessively burdening its inhabitants only in the historical center. The key values of tourist business conducted by entrepreneurs can be referred to two groups of companies: those with a formal business model and those not having such a model. The respondents' 
business responses not only concern the values generated for the enterprise, but also for tourists and the local community, and are referred to in the city's sustainable tourism development policy.

\section{Literature Review}

\subsection{Sustainable Business Models}

One of the modern strategic tools in managing an enterprise or any other organization is the business model. The evolution of this tool is evident in the variety of definitions used to describe it, especially in the 21st century, where it was initially referred to as an abstract concept or a description of relationships or ongoing processes. However, literature has been dominated by the tool importance of business models. According to the definition of Osterwalder and Pigneur [1], it is a conceptual tool containing a set of elements and their relationship with set goals, allowing the company's business logic to be exposed. It is a description of the value that an enterprise is able to provide to market segments and a description of the organization itself, along with its network connections with partners in order to create value. Teece [2] sees it as a practical application in designing or describing the architecture of mechanisms for creating, delivering, and capturing value. Prendeville and Bocken [3] refer to it as ordering business transactions between customers, partners, and suppliers as well as the organization, and their participation in creating and capturing value. Margaretta defines the business model as a characteristic of the described business in the form of a story explaining how the enterprise operates [4]. Often, it is also a description of the ongoing relationships between the components in the organization that lead to the creation and capture of its value [5].

Al-Debei et al. [6] portray business models in the form of an abstract textual or graphic representation of related model architecture structures developed by the organization, and all products and services that the organization proposes, and that are needed to achieve the goal.

The affordability and versatility of business models have led to the fact that, for two decades, the use of business models has been observed to expand not only to further industries (including business models of industrial, food, tourist, energy, etc. enterprises), but also to the specific dimensions of ongoing processes, taking into account the needs of a changing business environment. An example of such a specific model is its form, dedicated to enterprises wishing to implement the assumptions of sustainable development. Geissdoerfer [7] defines sustainable business models as a set of elements in which the interrelationships between these elements and their interactions with stakeholders create, deliver, capture, and exchange sustainable value for many stakeholders. Abdelkafi and Täuscher [8] see sustainable business models as a tool to integrate sustainable development principles into the company's value logic and the logic of value creation by the enterprise. Entering sustainable development principles into business operations can help protect the environment, but, as Porter and Kramer [9] state, can also be a source of competitive advantage and economic benefits for the enterprise.

Nosratabadi et al. [10] reviewed the work from various thematic areas. An interesting fact can also be seen in the literature analysis after 2007. The context of sustainable development in business models is most often taken up in the work of scientists from the United States and Great Britain as well as in China, with Americans taking up this topic in their research twice as often as the British and almost three times more often than the Chinese.

However, it should be noted that the adaptation of activities and solutions related to sustainable development is not only the direct impact of enterprises on the environment, but also on the immediate business environment (contractors, customers, recipients). Therefore, the implementation of sustainable development elements is often associated with obstacles.

The findings of the Cape Town Declaration on Responsible Tourism from 2018 [11] include the objectives of sustainable tourism. Another example relating to business models in tourism is the study of Peric and Wise [12], which is a holistic and in-depth analysis of how sports tourism experiences are delivered by looking at two existing case studies in Istria (Croatia). An important source of sustainable 
development activities in tourism are the Global Sustainable Tourism Council (GSTC) Criteria [13], which were developed for the implementation of "sustainable tourism" in the tourist company.

\subsection{Value for the Customer, Enterprise, and Society}

From the perspective of many approaches to the structure of the business model, the place and role of one of them is extremely significant: the element of value proposition for the customer. This element appears in almost all concepts, regardless of the number of components and the way they are grouped. However, considering that the value proposition is something, without which an enterprise loses the basic sense of functioning, and thus a set of products and services that generate value for a particular customer segment, the universality of its occurrence is understandable.

Customer value is a very broad concept. The cited definition of Osterwalder and Pigneur [1] defines it as a set of products and services that generate value for a particular customer segment as well as the reason why customers prefer the offer of a given company over the offer of its competitors. They also add that it is a value that solves customer problems or meets their needs. However, customer value is often complemented by business value, which is what the enterprise captures as part of its own business. Most often it is profit and other intangible assets.

As part of their business, tourism businesses also generate other values that are not related to what the customer or the enterprise itself gains [14]. This value is the social value of the business, determined by the tendency to pursue social goals in the form of activities and services that go beyond tourism. This may be, for example, therapeutic treatment provided as part of spa tourism or medical services provided as part of medical tourism, or activities that protect the natural environment and indigenous culture through the implementation of sustainable tourism [15]. However, it should be noted that the structure of these three categories of values is likely to change as soon as a certain level of tourist traffic load is reached. Therefore, in the second part of this article, efforts were made to simultaneously examine the value structure generated by the tourist enterprise and determine the level of burden on residents with the presence of tourists.

\subsection{Overtourism and How to Measure it}

One of the important problems of modern tourism is overtourism (i.e., the overload of tourist traffic on tourist destinations and the measurement of this load). Tourism space has its limitations resulting from the size of the usable area and its response to tourism traffic [16]. An important problem is determining the permissible volume of traffic, exceeding which could be considered excessive. In relation to cities and large tourist centers that are struggling with the invasion of tourists, indicators of the optimal level of sociopsychological capacity have been proposed [17]. In a very short time, the term overtourism has become a descriptor of the negative impact of tourism and refers to the problem of excess tourists in many cities. The discussion around overtourism has drawn attention to the negative consequences of unlimited tourism growth and also pointed out directions of restrictions and voluntary compromises aimed at effectively preventing growing problems [18].

The literature mentions other issues that are related or similar to overtourism. An example is the publication by Torres Outón [19], Jover, and Diaz-Parra [20], which refers to gentrification and touristification. For the sake of completeness, it is worth adding that the phenomenon of touristification includes processes caused by excessive tourist traffic that contribute to the destruction of the socio-cultural tissue of the city: they break down social networks and neighborhoods and erode local identities that are supplanted by marketing activities targeted at tourists [21]. Regarding the second concept, gentrification is a process of changing the character of a neighborhood through the influx of more affluent residents and businesses. Gentrification often shifts a neighborhood's racial/ethnic composition and average household income by developing new, more expensive housing, businesses, and improved resources [22].

It is very difficult to determine the assessment of the social effects of the influx of tourists. The level of tolerance of inhabitants toward the influx of tourists varies depending on local and private 
interests [23,24]. An important tool is the analysis of the limits of acceptable change (LAC) $[25,26]$. However, it should be noted that residents' tolerance for social difficulties may be greater due to economic benefits [27].

There are various ways of solving this issue, besides limiting the number of visitors. This may include:

- increasing the tourist capacity of reception areas, and

- making a variety of tourism forms and to build correct relationships between stakeholders who are involved in tourism [28-30].

The tool for measuring the residents' response to the occurrence of tourism traffic is the methodology proposed by Doxey [16,31], which has been used for over four decades. The literature also presents other methods of assessing the intensity of tourist traffic (e.g., with the help of the Baretje-Defert, Defert, Charvat and Schneider indicators) as well as accommodation density indicators and the use of accommodation potential and tourist enterprises (in all enterprises) [31-34]. Concepts that include measuring the capacity and tourist absorption of the area [35-37] or analyzing the development of the area through the typology of tourists visiting the area $[38,39]$ are also often used.

However, the simplicity of the Doxey index means that it is still used. An example of this is the research into assessing the attitudes of locals toward tourists and tourism in Dubai, a city of rapid development in the tourism industry in the Middle East [40]. Their research indicates that the tourism industry in this city can continue to grow without becoming antagonistic with the inhabitants. Similar research on the socio-cultural influences of tourism development have been conducted in Hungary's Lake Balaton [41] and the island of Mauritius [42].

Doxey $[33,34]$ assumes that the emergence of negative attitudes of inhabitants toward tourists is the result of exceeding the limits of the social carrying capacity (i.e., the ability to accept changes). Describing ongoing changes in the attitudes of inhabitants in four successive levels. The first level is euphoria, a phase in which residents experience enthusiasm and joy at the appearance of tourists. Satisfaction with this fact is reciprocal, as tourists enjoy a joyful reception and residents receive income. The second phase is apathy (i.e., stabilization of emotions toward tourists). Tourist traffic is becoming something ordinary and a tourist is an obvious element of earning of residents. In the third phase, which is irritation, an approximation of the volume of tourist traffic approaches the saturation point with tourists. This generally results in infrastructure development. In the fourth phase, antagonism, the tourist is perceived as the source of all that is bad. In place of courtesy, abuse and even fraud are increasingly creeping into relationships with tourists. The last phase, although not named by Doxey, is a permanent change of the area and its inhabitants, and often also the loss of tourist function.

\section{Materials and Methods}

The purpose of the article was to identify the values generated by tourist enterprises in the context of the occurrence of a specific level of overtourism using the example of the historic city of Krakow. To achieve this goal, empirical research was conducted among randomly selected inhabitants and entrepreneurs conducting business activities related to tourism in Krakow, Poland (i.e., in one of the cities most visited by tourists in Central Europe).

In 2019, Krakow had 780 thousand inhabitants and its administrative division included four main districts (i.e. Podgórze, Nowa Huta, Old Town, and Krowodrza) [43]. The most interesting areas for tourists is the Old Town, covering the urban layout of the historic old town with the royal castle (Wawel), the former Jewish district of Kazimierz, churches, and numerous museums where mainly hotels, apartments, restaurants, clubs, theatres, etc. are located. This district has the largest tourist crowds and there has been a rapid increase in the short-term tourist rental offers, causing gentrification.

Krakow is one of the most popular Polish tourist destinations. It belonged to the United Nations Educational, Scientific and Cultural Organization (UNESCO) Creative Cities Network in 2013, and the European Capital of Gastronomic Culture in 2019. The proof of the high significance of the problem 
of overtourism in Krakow is the development of a general Sustainable Tourism Policy Program for 2021-2028, under the patronage of the City of Krakow [44]. In 2019, Krakow was visited by as many as 14 million people, who spent almost PLN 7.5 billion during their stay in Krakow. The GDP generated by the tourist industry in Krakow is over $8 \%$ of the city's total GDP [43]. The pace of changes is also indicated by statistical data. The volume of tourist activity in Krakow has doubled in the last decade [45]. Tourism in Krakow generates 29,000 jobs [44,46], and tourist arrivals from abroad to Poland in 2014-2019 increased by one third (from 12.5 to 19.5 million tourists) [47,48].

The research tool used in the study was a research questionnaire made available to 518 respondents including 371 randomly selected residents of Krakow and 147 entrepreneurs operating in Krakow. A permanent feature for all respondents was permanent residence in one of the four main districts of Krakow or tourist activity there. The research questionnaire contained nine questions with an extensive structure. The first part of the questionnaire included questions that first classified the respondent to a specific group of respondents (residents/entrepreneurs), and then to a subgroup. In the case of entrepreneurs, subgroups were created by the criterion used, which was the generic scope of the business (hospitality, gastronomy, other tourist services), while in the case of city residents, the respondents were classified into a subgroup related to local origin and the relationship of professional work with tourism. The second part of the research questionnaire included questions aimed at assessing the impact of tourist traffic in Krakow on the daily lives of city residents and people conducting business activity there as well as the proposal of value in the business models of enterprises operating there.

The analysis of the answers obtained was made using the methodology proposed by Doxey by enabling respondents to choose one of five answers that most accurately determined their attitude to tourists. Table 1 presents the method of determining the level of tourism impact on residents and entrepreneurs, in which specific opinions were assigned an appropriate level of tourism load. The Doxey model was also supplemented with an extreme attitude, which expresses the complete degradation of the tourism (decline stage).

Table 1. Assigning standardized opinions to individual stages of development in tourist traffic load in the Doxey concept.

\begin{tabular}{|c|c|}
\hline Doxey Index & $\begin{array}{c}\text { Opinion Characterizing the Residents' and Entrepreneurs' Specific } \\
\text { Attitude }\end{array}$ \\
\hline Stage I: Euphoria & $\begin{array}{l}\text { I am glad that tourists come here, because it means income for the city, new } \\
\text { contacts, jobs, prestige ... }\end{array}$ \\
\hline Stage II: Apathy & $\begin{array}{c}\text { It is obvious that tourists come to us. It doesn't impress me. We have to show } \\
\text { hospitality ... }\end{array}$ \\
\hline Stage III: Irritation & $\begin{array}{l}\text { Unfortunately, I see more negative than positive sides to tourists coming to my } \\
\text { city. It is no longer the same city it used to be ... }\end{array}$ \\
\hline Stage IV: Antagonism & $\begin{array}{l}\text { Currently, tourists mainly mean problems. There are too many of them, which } \\
\text { reduces the quality of life for inhabitants. Something needs to be done about it, } \\
\text { e.g. introduce restrictions ... }\end{array}$ \\
\hline Stage V: Decline & I cannot tolerate tourists in my surroundings! \\
\hline
\end{tabular}

However, the respondents were asked to rate the load on a scale of $0-10$. The collected data were subjected to statistical analysis [49]. The level of the significance of differences between the obtained average values was also studied (Mann-Whitney test was used) [50], taking into account significance at the level of $\alpha \leq 0.05$. 


\section{Results of Research}

Empirical research was conducted on a sample of 518 respondents including 371 city residents (71.6\%) and 147 entrepreneurs conducting business activity in the analyzed tourist destination $(28.4 \%)$. Among the entrepreneurs participating in the research, every fifth provided hotel services $(19.9 \%)$ and $7.8 \%$ of the surveyed companies provided catering services. Entrepreneurs providing other tourist services than those above-mentioned were the dominant group $(72.3 \%)$. The age structure of the resident respondents indicates the dominance of people over 35 (51.0\%). More often than every third respondent ( $35.6 \%$ ) was $36-55$ years old, while every seventh was more than 55 years old.

More often than every second respondent $(56.6 \%)$ declared being of Krakow origin. It is also known that the majority of the surveyed residents were active in the field of tourism (51.0\%).

\subsection{Quantitative Analysis Results}

Quantitative analysis of the tourist traffic load showed that the load expressed on a scale of 0-10 was assessed at the level of optimal load (i.e., oscillating around an average rating of $5\left(\mathrm{x}_{\mathrm{Av}}=5.49 \pm\right.$ $2.81 ; \mathrm{Me}=5)$ ). However, this is the average result from the ratings of four individual districts. As expected, the distribution of loads in individual districts is not even. One of the districts showed an optimal load, while the others were either overloaded with tourism (Old Town $\mathrm{x}_{\mathrm{Av}}=7.43 \pm 2.4 ; \mathrm{Me}=$ 8 ) or showed an underload of tourists such as in Krowodrza and Nowa Huta, where tourists are still expected there to a larger extent than before $(\mathrm{Me}=4)$.

By not focusing the respondents' attention on the rated district, but on the whole city, a much higher average result $\left(\mathrm{x}_{\mathrm{Av}}=7.57 \pm 1.97 ; \mathrm{Me}=8\right)$ was obtained than in the case of the average result for the ratings of individual districts $\left(\mathrm{x}_{\mathrm{Av}}=5.49 \pm 2.81 ; \mathrm{Me}=5\right)$. This means that respondents rated the city's load based on the load perceived in the most tourist-borne district of this destination (Old Town).

Therefore, analyzing the results obtained for the whole city, it can be concluded that Krakow is struggling with an excessive number of tourists, but to a moderate degree. Assuming that the tourist traffic load within the $0-5$ limits is also a load not exceeding the level of critical capacity and tourist absorption, it can be stated that the limit of tourist capacity has been exceeded in Krakow. However, it does not seem to be a level that degrades the tourist function of the city, but the level of load is rather moderate or sometimes excessively burdensome for its inhabitants.

The origin of respondents from the city or outside the city had no effect on the expressed attitude toward tourists or the assessment of the city's tourist traffic load $(p>0.05)$. The fact of whether the respondent was employed in tourism or outside tourist activities had an impact on the attitude toward tourists $(p<0.001)$, which seems to be understandable, but also had an impact on the assessment of the tourist traffic load in the city $(p<0.001)$.

In the case of differences between the ratings of residents and entrepreneurs conducting their tourist activities in the city, significantly different notes can be seen in all of the analyzed variables. While entrepreneurs showed a lower comfort of doing business in the city than residents $(p=0.029)$, in the case of tourists, entrepreneurs had significantly higher scores than the residents $(p<0.001)$.

As far as the tourist traffic load in the city is concerned, it is worth noting that residents had a significantly higher load than entrepreneurs $(p<0.001)$. Considering the fact that entrepreneurs earn income from tourism, while among the residents, only every second was associated with tourism, the obtained result is understandable.

\subsection{Qualitative Analysis Results}

The obtained results regarding the ratio of residents to arriving tourists were verified using the model of changes in attitudes of inhabitants toward tourists, according to the Doxey concept. For this purpose, residents were asked to indicate the attitude that characterized their relationship toward tourists, according to the classification presented earlier in Table 1. 
In terms of assessment in individual districts, the answers of the majority of inhabitants in the Krakow districts surveyed indicated the first two phases of the Doxey model (i.e., euphoria and apathy). By almost the same percentage of respondents, which was about $40 \%$ (the difference between the percentage of people indicating these two phases generally only reached $\Delta=2-5 \%$ ). The Old Town, being the most burdened with tourists, is unique in this respect, where euphoria is strongly indicated, but, at the same time, had the highest percentage of people who described their attitude as antagonism $(13.6 \%)$.

However, the overall result obtained was an average assessment, taking into account the ratings of entrepreneurs and residents. An in-depth analysis of the results obtained indicates that these opinions did not coincide. While every third city inhabitant indicated the attitude of euphoria, expressed by the opinion: I am glad that tourists come here, because it means income for the city, new contacts, jobs, prestige ... (33.8\%), among the entrepreneurs, this attitude was shown by twice as many respondents (71.9\%). Among the residents, the attitude of conflict with tourists was expressed by $9.4 \%$ of people, while among the entrepreneurs, it was only $2.1 \%$. The structure of the residents' and entrepreneurs' attitudes is presented in Table 2.

Table 2. The structure of the residents' and entrepreneurs' attitudes toward tourists in accordance with the Doxey concept.

\begin{tabular}{cccc}
\hline Doxey Index [\%] & Inhabitants & Entrepreneurs & In General \\
\hline Stage I: Euphoria & $33.8 \%$ & $71.9 \%$ & $42.5 \%$ \\
\hline Stage II: Apathy & $36.9 \%$ & $14.6 \%$ & $31.7 \%$ \\
\hline Stage III: Irritation & $20.0 \%$ & $10.4 \%$ & $17.8 \%$ \\
\hline Stage IV: Antagonism & $9.4 \%$ & $2.1 \%$ & $7.7 \%$ \\
\hline Stage V: Decline & $0.0 \%$ & $1.0 \%$ & $0.2 \%$ \\
\hline & Source: Based on own study.
\end{tabular}

\subsection{Tourist Traffic Load Depending on the Use of the Business Model}

The analysis of the obtained results was also conducted in the direction of identifying differences between entrepreneurs using the business model and those who did not use it. Although the differences between the percentages of entrepreneurs with specific attitudes in both groups of analyzed entrepreneurs were not statistically significant, some differences were clearly noticeable. Entrepreneurs not using the formal business model more often showed euphoria from the presence of tourists $(66.04 \%$ $\Leftrightarrow 78.05 \%$ ), but the attitude of apathy and irritation was more often shown by entrepreneurs using the business model (Table 3 ).

Table 3. Results of average ratings expressed according to the Doxey model.

\begin{tabular}{ccccc}
\hline Doxey model & $\begin{array}{c}\text { Entrepreneurs } \\
\text { with A Business } \\
\text { Model }\end{array}$ & $\begin{array}{c}\text { Significance Level } \\
(\mathbf{p})\end{array}$ & $\begin{array}{c}\text { Entrepreneurs without } \\
\text { A Business Model }\end{array}$ & In General \\
\hline Euphoria & $66.04 \%$ & 0.2756 & $78.05 \%$ & $\mathbf{7 1 . 2 8 \%}$ \\
\hline Apathy & $18.87 \%$ & 0.6814 & $9.76 \%$ & $\mathbf{1 4 . 8 9 \%}$ \\
\hline Irritation & $11.32 \%$ & 0.0704 & $7.32 \%$ & $\mathbf{9 . 5 7 \%}$ \\
\hline Antagonism & $1.89 \%$ & 0.9604 & $2.44 \%$ & $\mathbf{2 . 1 3 \%}$ \\
\hline Decline & $1.89 \%$ & 0.9604 & $2.44 \%$ & $\mathbf{1 . 0 6 \%}$ \\
\hline
\end{tabular}




\subsection{Declared Value Proposition in Business Models}

Entrepreneurs were also asked about the value proposition for customers, the enterprise, and society. These values were declared by both those who used the business model and those who did not know the business models (Table 4).

Table 4. Comparison of the attitudes of residents and entrepreneurs of the main districts of Krakow.

\begin{tabular}{|c|c|}
\hline VALUE FOR TOURISTS & {$[\%]$} \\
\hline Interaction with family members, friends as well as encountered tourists and residents & $68.09 \%$ \\
\hline $\begin{array}{l}\text { Enabling tourists to rest by meeting their needs (accommodation, catering etc.) } \\
\text { (accommodation and catering services) }\end{array}$ & $63.83 \%$ \\
\hline $\begin{array}{l}\text { Providing cognitive, cultural, religious experiences., etc. by providing tourists with the } \\
\text { opportunity to commune with forms of culture and art (tourist services) }\end{array}$ & $58.51 \%$ \\
\hline $\begin{array}{c}\text { Achieving recreation effects (health, relaxation, beauty, better looks, sport results, etc.) } \\
\text { (recreational and spa services) }\end{array}$ & $52.13 \%$ \\
\hline Staying away from the everyday routine & $27.66 \%$ \\
\hline Other & $2.13 \%$ \\
\hline VALUE FOR ENTREPRENEURS & {$[\%]$} \\
\hline $\begin{array}{l}\text { Satisfaction with playing an important role in the chain of creating the tourist offer of the } \\
\text { city, region, and country }\end{array}$ & $88.30 \%$ \\
\hline The opportunity to develop and invest in one's own business & $79.79 \%$ \\
\hline Cooperation with suppliers and a team of colleagues & $47.87 \%$ \\
\hline Obtaining income to support the company & $25.53 \%$ \\
\hline Satisfaction of tourists from a feeling of meeting their needs & $19.15 \%$ \\
\hline Other & $3.19 \%$ \\
\hline VALUE FOR THE COMMUNITY & {$[\%]$} \\
\hline $\begin{array}{l}\text { Carrying out preventive actions against excessive tourist traffic loads (reduction in } \\
\text { pollution). }\end{array}$ & $72.34 \%$ \\
\hline Supporting the city by paying public levies (taxes etc.), creating jobs & $35.11 \%$ \\
\hline Playing an important social role in the city's economy & $28.72 \%$ \\
\hline Selection of ecological contractors (without plastic, old technologies, etc.) & $20.21 \%$ \\
\hline $\begin{array}{l}\text { Introduction of rules for the provision of services limiting tourist dysfunctions (disputes, } \\
\text { noise) }\end{array}$ & $11.70 \%$ \\
\hline Other & $7.45 \%$ \\
\hline
\end{tabular}

In the case of customer value, more than half of the entrepreneurs ( $>50 \%)$ appreciated values such as:

- The ability to interact with family members, friends as well as encountered tourists and residents;

- $\quad$ Enabling tourists to rest by meeting their needs (accommodation, catering, etc.);

- Providing cognitive, cultural, religious experiences, etc. by providing tourists with the opportunity to commune with forms of culture and art; and

- Achieving recreation effects (health, relaxation, beauty, better looks, sport results, etc.).

- Among the most appreciated values captured by enterprises are:

- Satisfaction with playing an important role in the chain of creating the tourist offers of the city, region, and country, and

- The opportunity to develop and invest in one's own business. 
The key social value indicated by entrepreneurs was conducting preventive measures against excessive tourist traffic loads (reduction of pollution). This is due to the significant air pollution in Krakow.

\section{Conclusions}

A comparison of the results obtained between enterprises declaring having and not having a business model indicates a great similarity in terms of the declared value propositions. However, three cases of significant differences between entrepreneurs were noticed.

The first of the differences was observed in the case of enterprise value (in terms of satisfaction with playing an important role in the chain of creating the tourist offer of the city, region, and country). Entrepreneurs with a business model more often declared satisfaction with this role, which was $62.26 \%$ of entrepreneurs, compared to $53.66 \%$ of entrepreneurs without a business model. It is, therefore, significant evidence that the awareness of the role in the economy of the area goes hand in hand with the awareness of the advantages of having structured business principles.

The next two differences relate to values for society, but this time the results are not clear. Entrepreneurs who do not use the business model (58.54\%) see more value from playing an important social role in the city's economy than those who have such a model (39.62\%). Over half of entrepreneurs with a business model saw their own role in the city's economy.

However, the introduction of the principles of providing services limiting tourist dysfunctions (disputes, noise, etc.) in an enterprise was more often declared by entrepreneurs who did not use a business model ( $85.37 \%)$, than those who had such a tool $(75.47 \%)$. This time, the issue of greater awareness of social impact did not accompany the use of the business model in conducting business.

Among other conclusions, it is worth quoting those that resulted from the obvious subjectivity of perception of the phenomenon of the presence of tourists in the city. While residents more often stressed the annoyance of tourism than entrepreneurs, the benefits of tourism in the city were more often appreciated by entrepreneurs. However, it seems reasonable to observe the percentage of entrepreneurs who poorly assessed the presence of tourists in the city and the residents who well assessed the impact of tourists.

One of the very important elements of this research was also noticing the diversity of perceived loads in individual city districts. While a moderate tourist traffic load was observed in the city, the inhabitants and entrepreneurs of individual districts showed different opinions on this subject. While the main tourist district of the city had an excessive load reaching 8 on the scale of quantified load $(1 \div 10)$, the other district only had a value of 4 and might mean an ability to take more tourists.

An important solution in the business models of enterprises operating in areas with a significant intensity of tourist traffic should become elements limiting the negative effects of tourist visits, and activities aimed at raising the awareness of guests brought in with their impact on the visited area. Appropriate education of tourists carried out by tourist enterprises may reduce the antagonisms on the part of the inhabitants, and thus extend the ability of entrepreneurs to benefit from tourism. Another important solution may be including the local community in the business models of tourism enterprises among key partners, and, at the same time, conducting activities supporting residents. However, it is not about increasing the financial (including tax) burden on enterprises, but about increasing the intensity of activities protecting inhabitants against tourism dysfunctions as well as strengthening the survival of indigenous cultural elements.

However, the proposed solutions should be sustainable through a permanent place in the business models, and at the same time, should be oriented toward the implementation of sustainable development, making these models sustainable.

An issue that may determine future research is to determine the strength and direction of the relationship between the three values in business models. These are the value proposition for the customer, the values captured by enterprises, and the value proposition for society. It is also important 
to identify the measurable reasons for restricting tourism activities to avoid the negative consequences of excessive tourist traffic.

Author Contributions: Conceptualization, A.R.S. and Z.K.; methodology, A.R.S. and Z.K.; software, A.R.S. and Z.K.; validation, A.R.S. and Z.K.; formal analysis, A.R.S. and Z.K.; investigation, A.R.S. and Z.K.; resources, A.R.S. and Z.K.; data curation, A.R.S. and Z.K.; writing-original draft preparation, A.R.S. and Z.K.; writing一review and editing, A.R.S.; visualization, A.R.S. and Z.K.; supervision, A.R.S. and Z.K.; project administration, A.R.S.; funding acquisition, A.R.S. All authors have read and agreed to the published version of the manuscript.

Funding: This research received funding by the National Science Center in Poland.

Acknowledgments: This paper was published as part of the research project 'A business model for health resort enterprises', No. 2017/25/B/HS4/00301 that was supervised and financed by the National Science Center in Poland, and as part of statutory research ROZ 1: BK-235/ROZ-1/2020 (13/010/BK_20/0042) at the Silesian University of Technology, Faculty of Organization and Management.

Conflicts of Interest: The authors declare no conflicts of interest. The funders had no role in the design of the study; in the collection, analyses, or interpretation of data; in the writing of the manuscript, or in the decision to publish the results.

\section{References}

1. Osterwalder, A.; Pigneur, Y. Business Model Generation: A Handbook for Visionaries, Game Changers, and Challengers; John Wiley and Sons: Hoboken, NJ, USA, 2010; p. 59.

2. Teece, D. Business models and dynamic capabilities. Long Range Plan. 2018, 51, 40-49. [CrossRef]

3. Prendeville, S.; Bocken, N. Sustainable Business Models through Service Design. Procedia Manuf. 2017, 8, 292-299. [CrossRef]

4. Magretta, J. Why business models matter. Harv. Bus. Rev. 2002, 80, 86-92.

5. Battistella, C.; Toni, A.; Zan, G.; Pessot, E. Cultivating business model agility through focused capabilities: Amultiple case study. J. Bus. Res. 2017, 73, 65-82. [CrossRef]

6. Al-Debei, M.; El-Haddadeh, R.; Avison, D. Defining the Business Model in the New World of Digital Business. In Proceedings of the Fourteenth Americas Conference on Information Systems, Toronto, ON, Canada, 14-17 August 2008.

7. Geissdoerfer, M.; Bocken, N.M.; Hultink, E.J. Design thinking to enhance the sustainable business modelling process-A workshop based on a value mapping process. J. Clean. Prod. 2016, 135, 1218-1232. [CrossRef]

8. Abdelkafi, N.; Täuscher, K. Business models for sustainability from a system dynamics perspective. Organ. Environ. 2016, 29, 74-96. [CrossRef]

9. Porter, M.E.; Kramer, M.R. The big idea: Creating shared value. Harv. Bus. Rev. 2011, 89, 62-77.

10. Nosratabadi, S.; Mosavi, A.; Shamshirband, S.; Zavadskas, E.K.; Rakotonirainy, A.; Wing Chau, K. Sustainable Business Models: A Review. Sustainability 2019, 11, 1663. [CrossRef]

11. Cape Town Declaration on Responsible Tourism. Available online: https://responsibletourismpartnership. org/cape-town-declaration-on-responsible-tourism/ (accessed on 1 August 2019).

12. Peric, M.; Wise, N. Understanding the delivery of experience: Conceptualising business models and sports tourism, assessing two case studies in Istria, Croatia. Local Econ. J. Local Econ. Policy Unit 2015, 30, 1000-1016. [CrossRef]

13. Global Sustainable Tourism Cuncil, GSTC Criteria for Hotels. GSTC Criteria for tour operators. GSTC Criteria for destinations. 2019. Available online: http://www.gstcouncil.org/gstc-criteria/ (accessed on 1 August 2019).

14. Butler, R.W.; Szromek, A.R. Incorporating the Value Proposition for Society with Business Models of Health Tourism Enterprises. Sustainability 2019, 11, 6711. [CrossRef]

15. Herman, K.; Szromek, A.R. A Business Creation in Post-Industrial Tourism Objects: Case of the Industrial Monuments Route. Sustainability 2019, 11, 1451.

16. Szromek, A. Wskaźniki Funkcji Turystycznych. Koncepcja Wskaźnika Funkcji Turystycznej i Uzdrowiskowej; Wyd. Politechniki Śląskiej: Gliwice, Poland, 2012.

17. Russo, A.P. The "Vicious Circle" of Tourism Development in Heritage Cities. Ann. Tour. Res. 2002, 29, 165-182. [CrossRef] 
18. Russo, A.P.; Scarnato, A. Barcelona in common: A new urban regime for the 21st-century tourist city? J. Urban Aff. 2018, 40, 1-20. [CrossRef]

19. Outón, S.M.T. Gentrification, touristification and revitalization of the Monumental Zone of Pontevedra, Spain. Int. J. Tour. Cities 2019, 2/5, 109-124. [CrossRef]

20. Jover, J.; Díaz-Parra, I. Gentrification, transnational gentrification and touristification in Seville, Spain. Urban Stud. 2019. [CrossRef]

21. Kubicki, P. Wpływ studentyfikacji i turystyfikacji na społeczno-kulturową przestrzeń miasta. Miasto. Pamięć i Przyszłość 2017, 2, 63-73. [CrossRef]

22. Health Effects of Gentrification. Centers for Disease Control. Available online: https://www.cdc.gov/ healthyplaces/healthtopics/gentrification.htm (accessed on 11 February 2020).

23. McCool, S.F.; Lime, D.W. Tourism Carrying Capacity: Tempting Fantasy or Useful Reality? J. Sustain. Tour. 2001, 9, 372-388. [CrossRef]

24. Saveriades, A. Establishing the social tourism carrying capacity for the tourist resorts of the east coast of the Republic of Cyprus. Tour. Manag. 2000, 21, 147-156. [CrossRef]

25. Lucas, R.C.; Stankey, G.H. Role of Research in Applying the Limits of Acceptable Change System. In Proceedings of the Southern Recreation Research Conference, Myrtle Beach, SC, USA, 28 February-1 March 1985; pp. 1-15.

26. Frauman, E.; Banks, S. Gateway community resident perceptions of tourism development: Incorporating Importance-Performance Analysis into a Limits of Acceptable Change framework. Tour. Manag. 2011, 32, 128-140. [CrossRef]

27. Nijs, V. Resident Attitudes towards Tourism; Testing the Resident Empowerment through Tourism Scale (RETS) in Bruges. Master's Thesis, MODUL University, Vienna, Austria, 2017.

28. Overtourism? Understanding and Managing Urban Tourism Growth beyond Perceptions; UNWTO: Madrid, Spain, 2018; Available online: https://www.e-unwto.org/doi/pdf/10.18111/9789284420070 (accessed on 20 November 2019).

29. Pearce, P.L. Limiting overtourism the desirable new behaviours of the smart tourist. In Proceedings of the Tourism Intelligence Forum (t-Forum) Global Exchange Conference 2018, Palma de Mallorca, Spain, 11-13 March 2018.

30. Bianchi, R.V. The 'Critical Turn' in Tourism Studies: A Radical Critique. Tour. Geogr. 2009, 11, 484-504. [CrossRef]

31. Baretje, R.; Defert, P. Aspects Economiques du Tourisme. Rev. Géographie Alp. 1973, 61-2, 319-320.

32. Defert, P. Le Taut de Fonction Touristique: Mise au point et critique. Cah. Tour. 1967, C-13, 33.

33. Doxey, G. A causation theory of visitor-resident irritants, methodology and research inferences. The impact of tourism. In Proceedings of the Sixth Annual Conference Proceedings of the Travel Research Association, San Diego, CA, USA, 8-11 September 1975.

34. Doxey, G.V. When enough's enough: The natives are restless in Old Niagara. Herit. Can. 1976, 2, $26-27$.

35. Butler, R.W. The concept of a tourist area cycle of evolution: Implications for management of resources. Can. Geogr. 1980, 24, 5-12. [CrossRef]

36. Butler, R.W. The resort cycle two decades on. In Reflections on Experience; Faulkner, B., Laws, E., Morcado, G., Eds.; Cassell: London, UK, 2000; pp. 284-299.

37. Butler, R.W. Tourism Area life Cycle. In Contemporary Tourism Reviews; Goodfellow Publishers Limited: Oxford, UK, 2011; pp. 7-21.

38. Plog, S.C. Why Destination Areas Rise and Fall in Popularity. The Cornell Hotel and Restaurant Administration Quarterly. Cornell Hotel Restaur. Adm. Q. 1974, 14, 55-58. [CrossRef]

39. Plog, S.C. Why Destination Areas Rise and Fall in Popularity. The Cornell Hotel and Restaurant Administration Quarterly. Cornell Hotel Restaur. Adm. Q. 2001, 42, 13-24. [CrossRef]

40. Zaidan, E.; Kovacs, J. Resident attitudes towards tourism and tourism growth: A case Study from the Middle East, Dubai in United Arab Emirates. Eur. J. Sustain. Dev. 2017, 6, 291-307. [CrossRef]

41. Ratz, T. Residents' perceptions of the socio-cultural impact of tourism at lake Balaton, Hungary. In Tourism and Sustainable Community Development; Richard, G., Hall, D., Eds.; Routledge: London, UK, 2003.

42. Soper, A.K. Developing Mauritianness: National Identity, Cultural Heritage Values and Tourism. J. Heritage Tour. 2007, 2, 94-109. [CrossRef]

43. CSO, Central Statistical Office. 2019. Available online: https://stat.gov.pl/ (accessed on 23 October 2019). 
44. Krakow City Hall. Sustainable Tourism Policy Cracow for the Years 2021-2028; Tourism Department: Krakow, Poland, 2020.

45. Kruczek, Z.; Mazanek, L. Krakow as a Tourist Metropolitan Area. Impact of Tourism on the Economy of the City. Studia Peregietica 2019, 26. [CrossRef]

46. Banaszkiewicz, M. A dissonant heritage site visited. The case of Nowa Huta in Kraków. J. Tour. Cult. Chang. 2017, 15, 185-197. [CrossRef]

47. Tourist Potential and its Exploitation in the Years 2014-2018-Regional Approach; GUS Statistical Office: Rzeszów, Poland, 2019.

48. Greenacre, M.; Hastie, T. The Geometric Interpretation of Correspondence Analysis. J. Am. Stat. Assoc. 1987, 82, 437-447. [CrossRef]

49. Stanisz, A. Biostatystyka; Wyd. Uniwersytetu Jagiellońskiego: Kraków, Poland, 2005; pp. 109-409.

50. Kendall, M.G. Multivariete Analysis; Charles Griffin: London, UK, 1975; pp. 3-198.

(C) 2020 by the authors. Licensee MDPI, Basel, Switzerland. This article is an open access article distributed under the terms and conditions of the Creative Commons Attribution (CC BY) license (http://creativecommons.org/licenses/by/4.0/). 